\title{
Editorial: Intercropping Systems in Sustainable Agriculture
}

\author{
Paulo Mazzafera ${ }^{1,2 *}$, José Laércio Favarin ${ }^{2}$ and Sara Adrián López de Andrade ${ }^{1}$ \\ ${ }^{1}$ Department of Plant Biology, Institute of Biology, University of Campinas, Campinas, Brazil, ${ }^{2}$ Department of Crop Science, \\ Luiz de Queiroz College of Agriculture - ESALQ/University of São Paulo, Piracicaba, Brazil
}

Keywords: intercrop, sustainability, nutrient cycling, nutrient use efficiency, water use efficiency

\section{Editorial on the Research Topic}

Intercropping Systems in Sustainable Agriculture

\section{INTRODUCTION}

Intercropping involves cultivating two or more crops in a field simultaneously, and is mainly practiced in regions where soils are relatively degraded. Intercropping is receiving increasing global interest as an agricultural practice as farmers strive to be more sustainable and maintain soil health (Glaze-Corcoran et al., 2020). Early research focused on supplying nitrogen by using legume species as intercropping plants (Stagnari et al., 2017). However, several non-cash plants are now used as cover crops to improve soil quality (Crusciol et al., 2012).

In this special issue, we received reports on recent research discussing the advantages and challenges of using intercropped systems in highly diverse world regions (sub-Saharan and Central Africa, North and South America, Asia, and Northern Europe).

Matteo Balderacchi, Independent Researcher, Milan, Italy

Reviewed by:

Autar Krishen Mattoo,

Agricultural Research Service (USDA),

United States

Deepranjan Sarkar

Banaras Hindu University, India

${ }^{*}$ Correspondence:

Paulo Mazzafera pmazza@unicamp.br

Specialty section:

This article was submitted to Crop Biology and Sustainability, a section of the journal Frontiers in Sustainable Food Systems

Received: 27 November 2020 Accepted: 18 January 2021 Published: 19 February 2021

Citation:

Mazzafera P, Favarin $\mathrm{JL}$ and Andrade SAL (2021) Editorial: Intercropping Systems in Sustainable Agriculture. Front. Sustain. Food Syst. 5:634361. doi: 10.3389/fsufs. 2021.634361

\section{TROPICAL GRASSES, NON-TILLAGE MANAGEMENT, AND NUTRIENT CYCLING}

The use of tropical grasses as cover and companion crops is increasing in conservation agriculture. Herein, we review recent scientific publications on the use of Urochloa species in agroecosystems, and their contributions to more secure and sustainable agriculture (Baptistella et al.). Urochloa species employed as forage or intercropped with cash crops such as soybean, coffee, or citrus may protect soil, reduce soil erosion, suppress weeds, and mobilize nutrients. Many of the practical benefits are related to the extensive Urochloa root system that contributes to the cycling of nutrients from deep soil layers, and to soil carbon storage, thereby improving soil fertility and quality. Nevertheless, appropriate management when introducing these perennial grasses is essential to ensure diversity in native ecosystems.

Crusciol, Mateus et al. demonstrated the viability of maize intercropped with tropical grasses, palisadegrass (Urochloa brizantha), or guineagrass (Megathyrus maximus), and highlighted the requirement for nitrogen fertilization to guarantee yields and profitability. Meat production and land use were increased when nitrogen fertilizer was applied, and these intercropping systems involving maize and forage grasses were considered a good option for farm diversification. In another article, Crusciol, Portugal et al. reported that intercropping with palisadegrass or guineagrass led to a reduction in rice yield compared with monocropped rice. Nitrogen fertilization of intercropped rice increased the grain yield, grain protein, and milled productivity of rice. Despite the negative impact on yield, the authors concluded that intercropping rice with forage grasses was more favorable from both economic and environmental perspectives. 
Palisadegrass and guineagrass sowing time was evaluated by Costa et al. in terms of forage production and quality, soybean yield, and soil chemical properties when used as intercrops under a no-tillage system. In an experiment in Central-West Brazil, annual crops and semi-evergreen crops were grown for three growing seasons. The authors showed that sowing guineagrass after maize harvest increased soybean nutrients and yield, and improved soil fertility, by increasing soil organic matter, exchangeable $\mathrm{Ca}$ and $\mathrm{Mg}$, and cation exchange capacity, while no-tillage reduced the $\mathrm{pH}$ value. Thus, this species can contribute to greater sustainability of tropical agriculture.

In a 5 year long-term study, de Azevedo et al. intercropped Urochloa ruzizienzis in high-density citrus (Tahiti acid lime) orchards, and compared four tillage systems: no-tillage, no tillage and herbicide, minimum tillage, and conventional tillage. Under non-irrigation conditions, incorporating $U$. ruziziensis in the no-tillage system increased fruit yield and improved water and nutrient-use efficiencies, as well as soil physical and chemical characteristics.

Pariz et al. studied a triple intercrop system with maize, pigeon pea (Cajanus cajan), and palisadegrass, combined with over-sown black oat. They concluded that the system improved nutrient cycling because the content of nutrients in standing plant residues and surface mulch was increased, resulting in better land- and nutrient-use efficiency.

In a soybean-wheat cropping system under no-tillage management, Moreira et al. showed that phosphate application as triple superphosphate efficiently supplied plants with phosphorus and increased grain yields, with stronger effects for fertilizer rates than application type on foliar phosphorus concentrations.

\section{CROP RESILIENCE IN THE FACE OF CLIMATE CHANGE}

Due to global warming, high temperatures and consequent drought have had a particularly detrimental impact in subSaharan Africa (Meehl et al., 2007; Spinoni et al., 2020). In this issue, Nyawade et al. and Chimonyo et al. present two examples of intercropped systems that contribute to increasing crop yield and improve water use efficiency (WUE). In the first paper, potato (Solanum tuberosum) intercropped with either dolichos (Lablab purpureus) or hairy vetch (Vicia sativa) and treated with granular silicon resulted in higher yield and better WUE under water deficit (Nyawade et al.). In the second, using an ex-ante approach, Chimonyo et al. used the Agricultural Production Systems sIMulator (APSIM) model to assess maize landraces intercropped with Bambara groundnut (Vigna subterranean). This intercropping system reduces land and water demand, and offers an inexpensive management strategy in environments projected to face water scarcity.

\section{INTERCROPPING AND SOIL MICROORGANISMS AS BIOFERTILIZERS}

Traditional nitrogen-fixing legumes have been used to improve soil fertility and staple crop performance for a long time, and a rich diversity of local species have been employed such as mung bean (Vigna radiata), Bambara groundnut, cowpea (Vigna unguiculata), black gram (Vigna mungo), and groundnut (Arachis hypogaea). Lengwati et al. evaluated the contribution of local food legumes as rotation crops for improving maize grain yield. They established a series of field experiments in South Africa, and used ${ }^{15} \mathrm{~N} /{ }^{14} \mathrm{~N}$ and ${ }^{13} \mathrm{C} / 1^{2} \mathrm{C}$ isotopic analyses to determine the percentage of nitrogen derived from symbiotic fixation. They also evaluated maize grain yield and nutrient concentrations. The results showed that the inclusion of nodulated legumes as biofertilizers enhanced the yield of the cereal crop and the nutritional quality of the grains.

Arbuscular mycorrhizal fungi (AMF) and plant growth-promoting rhizobacteria (PGPR) have been used as biofertilizers due to their beneficial effects on plant performance, mainly by mobilizing soil nutrients and producing phytohormones that stimulate root growth (Akinola and Babalola, 2021). In a comprehensive field study in Southern India over three successive cropping seasons, Mathimaran et al. demonstrated the potential of AMF and PGPR application in intercropping of pigeon pea and finger millet (Eleusine coracana). AMF (Ambispora leptoticha and Rhizophagus fasciculatus) and PGPR (Pseudomonas sp. strain MSSRFD $_{41}$ ) systematically improved grain yield for both pigeon pea and finger millet, mainly when applied as a consortium in transplanted pigeon pea-finger millet systems.

\section{FRUIT-BASED INTERCROPPING SYSTEMS}

Adverse climatic events contribute to a decline in soil fertility and an increase in pests and disease incidence in agriculture, reducing crop yield. Smallholders adopt bananabased intercropping systems in East and Central Africa, where fruit production contributes to food security and economic (Abele et al., 2007). In this issue, Gambart et al. quantified the profitability, sustainability, and nutritional yield of current banana-based systems using a FarmDESIGN model (Ditzler et al., 2019). A total of 120 farm households from two districts in Uganda were interviewed, and qualitative and quantitative information was collected. The agroecological intensification levels of farms were clustered according to key variables such as farm size, number of crop and hedge species, number of agroforestry species, number of shade- and drought-tolerant species, and production constraints and orientation. The authors demonstrated the disparity in agroecological practices and socioeconomic constraints between farmers, and the FarmDESIGN model was a valuable tool to assess farm performance, and may help to reduce costs and time-consuming trials.

In banana-based production systems, intercrops beneath the tree canopy are challenged by low light availability, and the balance between the spacing density of banana plants and the shade-tolerance of intercropped crops is crucial. In this issue, Blomme et al. revealed the need for careful selection of crops depending on canopy density and according to seasonally available water. Taro, soybean, mucuna, chili, eggplant, and Crotalaria sp. performed well in a low-density banana 
plantation. Cassava and soybean showed limited tolerance to shade. Chickpea and mucuna were suitable for the long dry season as they adapt to low water availability.

\section{FORAGE DIVERSITY, SOIL FUNGAL PATHOTROPHS, AND WEED CONTROL}

The concomitant growth of two or more crops in the same area without spatial rearrangement characterizes mixed intercropping (Glaze-Corcoran et al., 2020). In high latitudinal regions, the adoption of intercropped systems is challenging due to the short growing season and the wide temperature range through the year, especially extreme cold. In this issue, Lizarazo et al. reviewed sustainable mixed cropping systems in the BorealNemoral region and explored possible combinations of crops in terms of their unique features, advantages, and limitations. The need for more sustainable options for crop production has fostered interest in traditional cropping systems with mixed plant species. However, despite being a sustainable option with clear environmental benefits, mixed cropping systems still face resistance from end-users and industries, and natural constraints related to harsh climate conditions.

Bainard L. D. et al. reported the effects of increasing plant species diversity on forage productivity and soil chemical and biological characteristics in Canadian prairies. While in this system, mixtures performed better than monoculture, producing more nutritious forage, the abundance of fungal pathotrophs

\section{REFERENCES}

Abele, S., Twine, E., and Legg, C. (2007). Food Security in Eastern Africa and the Great Lakes. Ibadan: IITA.

Akinola, S. A., and Babalola, O. O. (2021). The fungal and archaeal community within plant rhizosphere: a review on their contribution to crop safety. J. Plant Nutr. 44, 600-618. doi: 10.1080/01904167.2020.1845376

Crusciol, C. A. C., Mateus, G. P., Nascente, A. S., Martins, P. O., Borghi, E., and Pariz, C. M. (2012). An innovative crop-forage intercrop system: early cycle soybean cultivars and palisadegrass. Agron. J. 104, 1085-1095. doi: 10.2134/agronj2012.0002

Ditzler, L., Komarek, A. M., Chiang, T. W., Alvarez, S., Chatterjee, S. A., Timler, C., et al. (2019). A model to examine farm household trade-offs and synergies with an application to smallholders in Vietnam. Agric. Syst. 173, 49-63. doi: 10.1016/j.agsy.2019.02.008

Glaze-Corcoran, S., Hashemi, M., Sadeghpour, A., Jahanzad, E., Afshar, R. K., Liu, X., et al. (2020). Understanding intercropping to improve agricultural resiliency and environmental sustainability. Adv. Agron. 162, 199-256. doi: 10.1016/bs.agron.2020.02.004

Meehl, G. A., Stocker, T. F., Collins, W. D., Friedlingstein, P., Gaye, A. T., Gregory, J. M., et al. (2007) "Global climate projections," in Climate Change 2007: The Physical Science Basis. Contribution of Working Group I to the Fourth in soils increased with plant diversity, highlighting the need to select forage species based on local growing conditions and plant-pathogen dynamics. However, in another study by this group reported in this issue, Bainard J. D. et al. showed that the diversification of forage species in the semiarid prairies of Canada is an effective way to control weeds, which may have particular relevance for reducing agrochemical inputs in these systems.

\section{FINAL REMARKS}

This Research Topic highlights the high diversity of intercropping systems around the world. The articles discuss the advantages of conservation agriculture practices, and the limitations and bottlenecks to be overcome. Overall, intercropping is a sustainable practice that can improve resource use efficiency for both nutrients and water, thereby facilitating low-input agricultural practices.

\section{AUTHOR CONTRIBUTIONS}

All authors listed have made a substantial, direct and intellectual contribution to the work, and approved it for publication.

\section{ACKNOWLEDGMENTS}

PM and JF thank Conselho Nacional de Desenvolvimento Científico e Tecnológico, Brazil, for research fellowships.
Assessment Report of the Intergovernmental Panel on Climate Change, eds S. Solomon, D. Qin, M. Manning, Z. Chen, M. Marquis, K. B. Averyt, M. Tignor, and H. L. Miller (Cambridge: Cambridge University Press), 747-845.

Spinoni, J., Barbosa, P., Bucchignani, E., Cassano, J., Cavazos, T., Christensen, J. H., et al. (2020). Future global meteorological drought hot spots: a study based on CORDEX Data. J. Climate 33, 3635-3661. doi: 10.1175/JCLI-D-190084.1

Stagnari, F., Maggio, A., Galieni, A., and Pisante, M. (2017). Multiple benefits of legumes for agriculture sustainability: an overview. Chem. Biol. Technol. Agric. 4:2. doi: 10.1186/s40538-016-0085-1

Conflict of Interest: The authors declare that the research was conducted in the absence of any commercial or financial relationships that could be construed as a potential conflict of interest.

Copyright (C) 2021 Mazzafera, Favarin and Andrade. This is an open-access article distributed under the terms of the Creative Commons Attribution License (CC BY). The use, distribution or reproduction in other forums is permitted, provided the original author(s) and the copyright owner(s) are credited and that the original publication in this journal is cited, in accordance with accepted academic practice. No use, distribution or reproduction is permitted which does not comply with these terms. 